\title{
Characterization of Cellulolytic Microorganisms Associated with Naturally Decomposing Waste Material
}

\author{
B.C. Game* , C.D. Deokar and A.C. Jadhav \\ Mahatma Phule Krishi Vidyapeeth, Rahuri, Dist. Ahmednagar, Maharashtra, India \\ *Corresponding author
}

\begin{tabular}{|l|}
\hline Ke y w o r d s \\
$\begin{array}{l}\text { Cellulolytic } \\
\text { microorganisms, } \\
\text { Carboxymethyl cellulase, } \\
\text { Endoglucanase, } \\
\text { Characterization }\end{array}$ \\
\hline Article Info \\
\hline $\begin{array}{l}\text { Accepted: } \\
\text { 12 March } 2018 \\
\text { Available Online: } \\
\text { 10 April } 2018\end{array}$ \\
\hline
\end{tabular}

\section{Introduction}

Microbial degradation of organic wastes plays a vital role in carbon recycling. For a longrange solution to resource problems of natural fertilizers, organic matter is available in large quantities in the form of agricultural wastes, forest residues and urban wastes. The undervalued organic waste can be converted to value-added products by using native cellulolytic microorganisms. Organic matter decomposition is carried out by various microorganisms including bacteria, fungi and actinomycetes. Different communities of microorganisms predominate during the various composting phases. There is practically no substance existing in nature that is not used by one microorganism or another. It is therefore necessary to identify the microorganisms present in the different processes, as several different species of microbes are usually involved. These 
microorganisms are also important to maintain nutrient flows from one system to another and to minimize ecological imbalance (Novinsak et al., 2008). Initial decomposition is carried by mesophilic microorganisms, which rapidly biodegrade the soluble and easily degradable compounds. As temperature increases, thermophiles take over. Temperature during decomposition process follows a pattern of rapid increase to $49^{\circ} \mathrm{C}$ to $60^{\circ} \mathrm{C}$ within 24 to 72 hours and is maintained for several weeks.

This is the active phase of decomposition, in which easily degradable compounds and oxygen are consumed, pathogens viz., Escherichia coli, Staphylococcus aureus, Bacillus subtilis, Clostridium botulinum and weed seeds are killed, and phytotoxins are eliminated. As the active composting phase subsides, temperature gradually declines to around $38^{\circ} \mathrm{C}$ and mesophilic microorganisms once again take over the other types of microorganisms and the curing phase begins (Fourti et al., 2008). Microbes play a key role as degraders during the composting process, and the microbiology of composting has been studied for decades, but there are still open questions regarding the microbiota in composting processes. Microorganisms that populate substrates during composting reflect the evolution and the performance of the composting process. Their metabolic paths lead to significant changes in the physical and chemical parameters of the composting substrate, and that, in turn, leads to changes in the microbial community structure. Hence, research was undertaken to study the cellulolytic microorganisms associated with naturally decomposing wastes.

\section{Materials and Methods}

\section{Isolation of microorganisms}

A total of 34 samples of naturally decomposing wastes were collected in paper bags from different places of 10 districts of Western Maharashtra. Isolation of bacteria, fungi and actinomycetes was carried out on specific medium i.e. nutrient agar medium, potato dextrose agar medium and starch casein agar medium, respectively by serial dilution and plating technique. Single isolated colonies of microorganisms were picked up, numbered and maintained on the respective agar medium for further studies after ascertaining their purity.

\section{Screening of cellulolytic microorganisms}

A preliminary qualitative analysis for cellulolytic activity was conducted following the protocol of Hankin and Anagnostakis (1977).

The microorganisms were grown in duplicate on cellulose amended Czapek's mineral salt agar medium. To inoculate solid media, the microorganisms were suspended in $5 \mathrm{ml}$ distilled water in test tubes. Drop of each suspension was applied to the surface of solidified test media. The inoculated plates were incubated at $28+2^{\circ} \mathrm{C}$ in BOD incubator for 6 days. At the end of incubation, to visualize the hydrolysis zone, the agar medium was flooded with an aqueous solution of Congo red (1\% w/v) for 15 min. Congo red solution was then poured off, and the plates were further treated by flooding with $1 \mathrm{M}$ $\mathrm{NaCl}$ solution for $15 \mathrm{~min}$. The ratio of the clear zone diameter to colony diameter was measured. The largest ratio was assumed to contain the highest cellulase activity.

\section{Endoglucanase assay}

Cellulase activity of most efficient 17 bacteria, 20 fungi and 19 actinomycetes isolates was confirmed by endoglucanase assay as described by Miller et al., (1960) and Mandels and Weber (1969). The selected isolates were grown in Czapek's mineral salt broth at $28 \pm 2$ 
${ }^{\circ} \mathrm{C}$ in incubator with stirrer. The supernatant of culture broth centrifuged at $5000 \mathrm{rpm}$ for 20 min. at $4{ }^{\circ} \mathrm{C}$ served as enzyme source. The culture filtrate $0.5 \mathrm{ml}$ was added to $0.5 \mathrm{ml}$ of $1 \%$ carboxymethyl cellulose sodium salt prepared in $0.05 \mathrm{M}$ sodium citrate buffer $(\mathrm{pH}$ 4.8) in a test tube.

The mixture was incubated at $50{ }^{\circ} \mathrm{C}$ for 30 min. Reaction was terminated by adding 3.0 $\mathrm{ml}$ dinitrosalicylic acid reagent subsequently placing the reagent tubes in water bath at 100 ${ }^{\circ} \mathrm{C}$ for $5 \mathrm{~min}$. After boiling, the tubes were transferred immediately to a cold water bath. Distilled water $20 \mathrm{ml}$ was added to the tubes and mixed by completely inverting the tubes several times.

Glucose standard solution was used instead of the sample simultaneously for preparing glucose standard curve. The colour so formed was measured against spectro zero at $540 \mathrm{~nm}$. The enzyme activity was expressed in units as the amount of enzyme required to release 1 $\mu$ mol of reducing sugar as glucose equivalent $\mathrm{min} / \mathrm{g}$ of the enzyme sample.

\section{Characterization and identification of cellulolytic microorganisms}

The selected seventeen cellulolytic bacterial isolates were identified on the basis of morphological and biochemical characterization as per the standard procedures and keys given by Barthalomew and Mittewer (1950), Cappuccino and Sherman (1992) and Anonymous (1957). Twenty cellulolytic fungal isolates were identified on the basis of cultural and microscopic features as described by Subramanian (1971), Barnett and Hunter (1972) and Aneja (2003). Nineteen cellulolytic actinomycetes were identified on the basis of morphological and biochemical characterization according to the procedures and keys by Waksman (1961), Lechevalier (1989) and Cappuccino and Sherman (1992).

\section{Results and Discussion}

\section{Isolation of microorganisms}

The population of bacteria, fungi and actinomycetes varied from 0.3 to $42.0 \times 10^{5}$, 0.0 to $17.0 \times 10^{5}, 0.0$ to $12.0 \times 10^{5} \mathrm{cfu} / \mathrm{g}$ of dry matter, respectively in different waste samples. Thirty four samples yielded 64 bacteria, 49 fungi and 63 actinomycetes isolates. The pure culture of isolates was stored at $4{ }^{\circ} \mathrm{C}$ in refrigerator and used as per necessity of work.

\section{Screening of cellulolytic microorganisms}

Cellulolytic microorganisms create a clearing zone around the colony on cellulose amended media. A higher production of cellulase when carboxymethyl cellulose (CMC) served as substrate may be as a result of induction of the enzyme, since cellulase is known to be universal inducer of cellulose synthesis. Several research workers (Teather and wood, 1982; Hendricks et al., 1995; Ariffin et al., 2006) screened the microorganisms for cellulolytic activity on the basis of zone clearing ability.

Out of 64 bacterial isolates only 17 isolates showed zone clearing indicating cellulase enzyme activity. Among the cellulolytic bacteria maximum cellulase activity was in isolate B-30 $(3.48 \mathrm{~cm})$ followed by isolate B$28(2.98 \mathrm{~cm})$. These results are in conformity with the results of $\mathrm{Lu}$ et al., (2005) who screened fifteen mesophilic bacteria which showed the ability to develop clearing zones around their colonies ranging from 2.55 to $6.40 \mathrm{~cm}$. Similar results have also been reported by Ariffin et al., (2006), Shankar et al., (2011) and Majidi et al., (2011).

Out of 49 fungal isolates tested, 30 isolates were able to hydrolyze cellulose. Maximum cellulase activity was shown by isolate F-13 
and F-24 (1.18 cm). Ray and Rath ((2007) found that two fungi viz., T. viride and $T$. harzianum showed higher activity with 6.4 and $6.2 \mathrm{~cm}$ clearance zone, respectively. Gautam et al., (2010) recorded cellulolytic activity of 87 fungal isolates ranging from 1.5 to $4.7 \mathrm{~cm}$. The work of Shahriarinour et al., (2011) also supports the above results.

Sixty three actinomycetes isolates were screened for cellulase activity, out of which 57 isolates showed zone clearance ability. The cellulase activity of cellulolytic actinomycetes ranged from 1.05 to $7.78 \mathrm{~cm}$. The maximum cellulase activity was shown by isolate A-41 $(7.78 \mathrm{~cm})$ followed by isolate A-40 $(5.30 \mathrm{~cm})$.

Jeffrey and Azrizal (2007) screened a total of 282 isolates of actinomycetes for cellulase activity, out of which 106 isolates gave positive results, with the ratio of halo zones to colony diameter between 3.00 and $4.60 \mathrm{~cm}$. Similar results have been reported by El-Sersy et al., (2010).

\section{Endoglucanase assay}

The assay for endoglucanase activity is based on the ability of the cellulase enzyme produced by the strains to hydrolyze CMC to reducing sugars. Ezekiel et al., (2010) revealed that $\mathrm{CMC}$ medium was a more favorable medium for the induction of endoglucanase enzyme in most of the isolates. The most efficient 17 bacteria, 20 fungi and 19 actinomycetes isolates were studied for endoglucanase activity (Table 1).

In the present studies, it was found that all the selected bacterial isolates were positive for endoglucanase assay. The endoglucanase activity ranged from 0.034 to $0.130 \mathrm{U} / \mathrm{ml}$. Highest endoglucanase activity was found in isolate B-37 $(0.130 \mathrm{U} / \mathrm{ml})$ followed by B-28 (0.121 U/ml). Ariffin et al., (2008) studied endoglucanase production of aerobic bacterium Bacillus pumilus EB3 and activity recorded was $0.076 \mathrm{U} / \mathrm{ml}$. Acharya and Chaudhary (2011) estimated endoglucanase activity of two bacteria Bacillus licheniformis and Bacillus sp. and recorded activity 0.388 and $0.342 \mathrm{U} / \mathrm{ml}$, respectively. Gupta et al., (2012) estimated endoglucanase activity of eight isolates of cellulose-degrading bacteria which ranged from 0.162 to $0.400 \mathrm{U} / \mathrm{ml}$.

All the selected 20 fungal isolates were also found positive for endoglucanase activity. The endoglucanase activity shown by isolates ranged from 0.012 to $0.099 \mathrm{U} / \mathrm{ml}$.

The maximum activity was shown by isolate F-13 (0.099 U/ml), followed by F-24 (0.087 $\mathrm{U} / \mathrm{ml})$. Present results are in conformity with the results of Jahangeer et al., (2005) who studied endoglucanase assay of 6 Aspergillus isolates and reported that the activity ranged from 0.640 to $1.240 \mathrm{U} / \mathrm{ml}$. Gautam et al., (2010) estimated the endoglucanase activity of fungal strains where maximum activity recorded was $0.976 \mathrm{U} / \mathrm{ml}$.

All the selected isolates of actinomycetes were positive for endoglucanase activity. The endoglucanase activity of isolates ranged from 0.068 to $0.204 \mathrm{U} / \mathrm{ml}$. The maximum enzyme activity was shown by isolate A-41 (0.204 $\mathrm{U} / \mathrm{ml})$ followed by isolate A-40 $(0.192 \mathrm{U} / \mathrm{ml})$. Jaradat et al., (2008) reported that Streptomyces sp. strain $\mathrm{J} 2$ showed highest endoglucanase activity of $0.432 \mathrm{U} / \mathrm{ml}$. Golinska and Dahm (2011) analyzed endoglucanase activity of 20 strains of actinomycetes.

The results ranged from 0.007 to $0.128 \mathrm{U} / \mathrm{ml}$. Singh and Kapoor (2013) reported that endoglucanase activity of efficient isolate of Streptomyces sp. MSC702 was $0.010 \mathrm{U} / \mathrm{ml}$. The present results are thus, in conformity with the work done by earlier research workers. 
Table.1 Endoglucanase activity of selected cellulolytic microorganisms

\begin{tabular}{|c|c|c|c|c|c|}
\hline \multicolumn{2}{|c|}{ Bacterial isolates } & \multicolumn{2}{|c|}{ Fungal isolates } & \multicolumn{2}{|c|}{ Actinomycetes isolates } \\
\hline Isolate No. & $\begin{array}{l}\text { Endoglucanase } \\
\text { activity }(\mathrm{U} / \mathrm{ml})\end{array}$ & Isolate No. & $\begin{array}{l}\text { Endoglucanase } \\
\text { activity (U/ml) }\end{array}$ & Isolate No. & $\begin{array}{l}\text { Endoglucanase } \\
\text { activity }(\mathrm{U} / \mathrm{ml})\end{array}$ \\
\hline B-4 & 0.088 & F-3 & 0.036 & A-4 & 0.145 \\
\hline B-11 & 0.060 & F-4 & 0.050 & A-15 & 0.167 \\
\hline B-13 & 0.056 & F-9 & 0.025 & A-17 & 0.160 \\
\hline B-15 & 0.055 & F-12 & 0.022 & A-18 & 0.126 \\
\hline B-24 & 0.075 & F-13 & 0.099 & A-20 & 0.090 \\
\hline B-26 & 0.106 & F-14 & 0.030 & A-22 & 0.165 \\
\hline B-27 & 0.108 & F-16 & 0.044 & A-24 & 0.172 \\
\hline B-28 & 0.121 & F-17 & 0.027 & A-29 & 0.137 \\
\hline B-30 & 0.130 & F-18 & 0.017 & A-35 & 0.179 \\
\hline B-37 & 0.034 & F-19 & 0.022 & A-38 & 0.132 \\
\hline B-38 & 0.085 & F-24 & 0.087 & A-40 & 0.192 \\
\hline B-42 & 0.044 & F-25 & 0.030 & A-41 & 0.204 \\
\hline B-46 & 0.067 & $\mathrm{~F}-27$ & 0.039 & A-42 & 0.103 \\
\hline B-51 & 0.079 & F-31 & 0.047 & A-46 & 0.140 \\
\hline B-53 & 0.049 & F-32 & 0.060 & A-47 & 0.068 \\
\hline B-57 & 0.040 & F-33 & 0.051 & A-48 & 0.124 \\
\hline B-64 & 0.105 & F-34 & 0.054 & A-52 & 0.133 \\
\hline & & F-35 & 0.052 & A-62 & 0.144 \\
\hline & & F-37 & 0.027 & A-63 & 0.103 \\
\hline & & F-44 & 0.012 & & \\
\hline
\end{tabular}

Table.3 Morphological and biochemical characteristics of cellulolytic actinomycetes

\begin{tabular}{|c|c|c|c|}
\hline $\begin{array}{c}\text { Isolate } \\
\text { No. }\end{array}$ & $\begin{array}{c}\text { Aerial mycelium } \\
\text { Colour }\end{array}$ & Spore chain morphology & $\begin{array}{c}\mathrm{H}_{2} \mathrm{~S} \\
\text { production }\end{array}$ \\
\hline A-4 & Grey & Retinaculiaperti, spores in short chains and individuals & + \\
\hline A-15 & Grey & Rectiflexibles, spores in long chains & - \\
\hline A-17 & White & Rectiflexibles, spores in long chains & - \\
\hline A-18 & Whitish grey & Retinaculiaperti, spores in long chains with open loops & - \\
\hline A-20 & White & Retinaculiaperti, spores in long chains with open loops & - \\
\hline A-22 & Whitish grey & Rectiflexibles, spores in long chains & + \\
\hline A-24 & White & Rectiflexibles, spores in long chains & - \\
\hline A-29 & Grey & Retinaculiaperti, spores in long chains with open loops & - \\
\hline A-35 & Grey & Retinaculiaperti, spores in long chains with open loops & - \\
\hline A-38 & Grey & Retinaculiaperti, spores in long chains with open loops & - \\
\hline A-40 & Whitish grey & Retinaculiaperti, spores in short chains & - \\
\hline A-41 & Grey & Rectiflexibles, spores in short chains & + \\
\hline A-42 & Light grey & Retinaculiaperti, spores in long chains with loops & - \\
\hline A-46 & Grey & Rectiflexibles, spores in short chains & - \\
\hline A-47 & Grey & Retinaculiaperti, spores in long chains with loops & - \\
\hline A-48 & Grey & Retinaculiaperti, spores in long chains with loops & - \\
\hline $\mathbf{A}-\mathbf{5 2}$ & Yellowish white & Rectiflexibles, spores in long chains & + \\
\hline A-62 & Pinkish white & Retinaculiaperti, spores in long chains with loops & - \\
\hline A-63 & grey & Retinaculiaperti, spores in long chains with loops & - \\
\hline
\end{tabular}

All isolates were positive for gram reaction, catalase, oxidase and gelatin liquefaction tests while negative for acid fast staining 
Table.2 Morphological and biochemical characteristics of cellulolytic bacteria

\begin{tabular}{|c|c|c|c|c|c|c|c|c|c|c|c|}
\hline \multirow{2}{*}{$\begin{array}{c}\text { Isolate } \\
\text { No }\end{array}$} & \multicolumn{3}{|c|}{ Colony morphology } & \multirow{2}{*}{$\begin{array}{l}\text { Gram } \\
\text { reaction }\end{array}$} & \multirow{2}{*}{$\begin{array}{l}\text { Endospor } \\
\text { e staining }\end{array}$} & \multirow[t]{2}{*}{ Cell shape } & \multirow[t]{2}{*}{ Size $(\mu \mathrm{m})$} & \multirow{2}{*}{$\begin{array}{c}\text { Citrate } \\
\text { test }\end{array}$} & \multirow{2}{*}{$\begin{array}{c}\text { Oxidas } \\
\text { e test }\end{array}$} & \multirow{2}{*}{$\begin{array}{l}\text { Motilit } \\
\text { y test }\end{array}$} & \multirow[t]{2}{*}{ Identification } \\
\hline & Colour & Shape & Elevation & & & & & & & & \\
\hline B-4 & Creamy white & Punctiform & Raised & Positive & Negative & $\begin{array}{l}\text { Oval to } \\
\text { round }\end{array}$ & $0.9-1.1$ & - & + & + & Cellulomonas \\
\hline B-11 & Light brown & Circular & Flat & Positive & Positive & $\begin{array}{l}\text { Rod chain } \\
\text { and pair }\end{array}$ & $0.7-0.8 \times 3.6-3.8$ & - & + & + & Bacillus \\
\hline B-13 & Light brown & Circular & Flat & Positive & Positive & $\begin{array}{l}\text { Rod chain } \\
\text { and pair }\end{array}$ & $0.7-0.9 \times 3.7-3.9$ & - & + & + & Bacillus \\
\hline B-15 & Light brown & Circular & Flat & Positive & Positive & $\begin{array}{l}\text { Rod chain } \\
\text { and pair }\end{array}$ & $0.6-0.8 \times 3.4-3.6$ & + & + & + & Bacillus \\
\hline B-24 & Yellow & Punctiform & Raised & Negative & Negative & Rod isolated & $0.4-0.6 \times 0.9-1.1$ & + & + & - & Pseudomonas \\
\hline B-26 & Yellow & Punctiform & Raised & Negative & Negative & Rod isolated & $0.4-0.5 \times 1.0-1.5$ & - & + & - & Pseudomonas \\
\hline B-27 & Light brown & Circular & Flat & Positive & Positive & $\begin{array}{l}\text { Rod chain } \\
\text { and pair }\end{array}$ & $0.7-0.8 \times 3.4-3.6$ & + & + & + & Bacillus \\
\hline B-28 & Light brown & Circular & Flat & Positive & Positive & $\begin{array}{l}\text { Rod chain } \\
\text { and pair }\end{array}$ & $0.8-0.9 \times 4.0-4.2$ & - & + & + & Bacillus \\
\hline B-30 & Creamy white & Circular & Raised & Positive & Negative & Cocci & $1.0-1.2$ & + & - & - & Staphylococcus \\
\hline B-37 & Light brown & Circular & Flat & Positive & Positive & $\begin{array}{l}\text { Rod chain } \\
\text { and pair }\end{array}$ & $0.6-0.8 \times 3.3-3.6$ & - & + & + & Bacillus \\
\hline B-38 & Light brown & Circular & Flat & Positive & Positive & $\begin{array}{l}\text { Rod chain } \\
\text { and pair }\end{array}$ & $0.7-0.9 \times 3.4-3.6$ & - & + & + & Bacillus \\
\hline B-42 & Light brown & Circular & Raised & Positive & Positive & $\begin{array}{l}\text { Rod chain } \\
\text { and pair }\end{array}$ & $0.8-0.9 \times 4.0-4.2$ & - & + & + & Bacillus \\
\hline $\bar{B}-46$ & Light brown & Circular & Flat & Positive & Positive & $\begin{array}{l}\text { Rod chain } \\
\text { and pair }\end{array}$ & $0.5-0.7 \times 3.2-3.6$ & - & + & + & Bacillus \\
\hline B-51 & Light brown & Circular & Umbonate & Positive & Positive & $\begin{array}{l}\text { Rod chain } \\
\text { and pair }\end{array}$ & $0.6-0.8 \times 3.0-3.2$ & - & + & + & Bacillus \\
\hline B-53 & Pale yellow & Punctiform & Flat & Positive & Negative & $\begin{array}{c}\text { Cocci } \\
\text { clusters }\end{array}$ & $0.7-0.9$ & - & - & - & Micrococcus \\
\hline B-57 & Light brown & Circular & Flat & Positive & Positive & $\begin{array}{l}\text { Rod chain } \\
\text { and pair }\end{array}$ & $0.6-0.9 \times 4.3-4.6$ & - & + & + & Bacillus \\
\hline B-64 & Yellow & $\begin{array}{c}\text { Punctifor } \\
\text { m }\end{array}$ & Raised & Negative & Negative & $\begin{array}{l}\text { Rod chain } \\
\text { and pair }\end{array}$ & $0.5-0.6 \times 1.0-1.4$ & - & + & - & Pseudomonas \\
\hline
\end{tabular}

All the isolates were negative for indole production, $\mathrm{MR}-\mathrm{VP}, \mathrm{H}_{2} \mathrm{~S}$ and phenylalanine deaminase test, while positive for catalase test 


\section{Characterization and identification of cellulolytic microorganisms}

The distinct variation in cell morphology among the different bacterial isolates was noticed (Table 2). Out of the 17 isolates, 11 produced circular, light brown colored and flat colonies. These isolates were rod shaped in pairs and chains with size ranging from $0.5-0.7 \times 3.2-3.6$ to $0.8-0.9 \times 4.0-4.2 \mu \mathrm{m}$ and were positive for motility test, oxidase test, catalase test, gram reaction and endospore staining. These isolates were identified as Bacillus spp and was the most predominant genera. Three colonies were yellowish, raised and punctiform in shape. These isolates were isolated and rod shaped with size ranging from $0.4-0.6 \times 0.9-1.1$ to $0.4-0.5 \times 1.0-1.5 \mu \mathrm{m}$ and were negative for motility test, gram reaction and endospore staining. These isolates were identified as Pseudomonas spp. The colony of isolate identified as Cellulomonas sp. was creamy white, punctiform and with raised elevation. The isolate was oval to round in shape with size 0.9 to $1.1 \mu \mathrm{m}$ in diameter, positive for gram reaction, motility test, catalase test and oxidase test. The colony of isolate identified as Staphylococcus sp. was creamy white, circular and with raised elevation. The isolate was cocci with size 1.0 to $1.2 \mu \mathrm{m}$ in diameter, positive for gram reaction and catalase test, while negative for motility and oxidase test. The single colony of isolate identified as Micrococcus sp. was pale yellow, punctiform with flat elevation. The isolate was cocci in clusters with size 0.7 to $0.9 \mu \mathrm{m}$ in diameter, positive for gram reaction and catalase test, while negative for motility and oxidase test. All the 17 bacterial isolates were negative for indole production, methyl red test, VogesProskauer test, $\mathrm{H}_{2} \mathrm{~S}$ test and phenyl-alanine deaminase test. Several workers (Shiva Reddy et al., 2010; Mirdamadian et al., 2011; Otajevwo et al., 2011) reported similar characteristics.
Twenty fungal isolates were identified by microscopic observations and colony morphology. Three distinct groups of Aspergillus isolates were formed. The first group comprised of ten isolates producing Cinnamon-buff to sand brown colour colony on potato dextrose agar media. Hyphae were colourless while conidial heads compact, columnar and biseriate. These isolates were identified as Aspergillus terreus. Second group comprised of five isolates having yellow colony at first which quickly become bright to dark yellow green with age. Hyphae in this group were colourless, conidial head typically radiate, biseriate. These isolates were identified as Aspergillus flavus. Third group comprised of five isolates having velvety textured colony with white mycelium spreading rapidly with dense layer of dark brown to black spores. Hyphae were colourless, conidial head biseriate, large, globose, dark brown, becoming radiate and tend to split into several loose columns with age. This group belonged to Aspergillus niger. Several research workers (Jahangeer et al., 2005; Rathnan et al., 2012; Naveenkumar and Thippeswamy, 2013; Adeyemo et al., 2013) identified Aspergillus on the basis of routine cultural and morphological characteristics and noted similar characters.

All the nineteen actinomycetes isolates studied were gram positive and non-acid fast in reaction (Table 3). There were 14 isolates having grey to whitish grey aerial mycelium colour, 3 isolates were whitish in colour while 2 isolates were yellowish white and pinkish white in colour. Spores of aerial mycelium and substrate mycelium in all the isolates were in chain and hence identified as Streptomyces spp. Twelve isolates were retinaculiaperti in spore chain morphology and 7 isolates were rectiflexibles. All the 19 isolates showed good to excellent growth on starch casein agar medium. The present results are in conformity with those of Oskay 
et al., (2004) and Reddy et al., (2011) who reported that actinomycetes are filamentous rod shaped bacteria, gram positive but nonacid fast in reaction. The observations of several research workers (Krishna Kumari et al., 2006; Nonoh et al., 2010; Mythili and Ayyappa Das, 2011) supports the noted characteristics of Streptomyces $\mathrm{sp}$.

Considerble population of bacteria, fungi and actinomycetes is associated with the naturally decomposing waste material. Bacillus, Pseudomonas, Cellulomonas, Staphylococcus and Micrococcus genera was found associated with decomposing material, where Bacillus was most predominant group while among fungi, Aspergillus spp. was predominant. Streptomyces spp was the predominant genera of actinomycetes associated with decomposition process. Microbes play a significant role in decomposition of organic waste, hence these cellulolytic microorganisms can be exploited for enhancing the decomposition rate in composting piles.

\section{Acknowledgements}

Authors are thankful to the Head, Department of Plant Pathology and Agricultural Microbiology, Mahatma Phule Krishi Vidyapeeth, Rahuri, Dist. Ahmednagar (MS) for providing necessary facilities during the investigations.

\section{References}

Acharya, S. and Chaudhary, A. 2011. Effect of nutritional and environmental factors on cellulases activity by thermophilic bacteria isolated from hot spring. J. Sci. Indust. Res. 70(2): 142-148.

Adeyemo, I.A., Adetoyi, O.E., Oni, M.O., Ayodele, M.J. and Olayemi, A.B. 2013. Studies on degradation of waste papers using microflora/microbial consortia isolated from refuse dumpsites in Iiorin metropolis. Int. J. Biotechnol. Food Sci. 1(1): 13-22.

Aneja, K.R. 2003. Experiments in Microbiology, Plant Pathology and Biotechnology. New Age International Publishers, New Delhi, India. pp. 1-607.

Anonymous. 1957. Manual of microbiological methods. McGrew Hill Book Company Inc., New York, p. 127.

Ariffin, H., Abdullah, N., Umi Kalsom, M.S., Shirai, Y. and Hassan, M.A. 2006. Production and characterization of cellulase by Bacillus pumilus EB3. Internat. J. Engg. Technol. 3(1): 47-53.

Ariffin, H., Hassan, M.A., Md Shaikh, U.K., Abdullah, N., Ghazali, F.M. and Shirai, Y. 2008. Production of bacterial endoglucanase from pretreated oil palm empty fruit bunch by Bacillus pumilus EB3. J. Biosci. Bioengg. 106(3): 231-236.

Barnett, H.L. and Hunter, B.B. 1972. Illustrated Genera of Imperfect Fungi. $2^{\text {nd }} \mathrm{Ed}$. Minneapolis Burgess Publishing Co., Minneapolis. pp 1-241.

Barthalomew, J.W. and Mittewer, T. 1950. A simplified bacterial strain. Stain Technol. 25: 153.

Cappuccino, J.G. and Sherman, N. 1992. Microbiology: A Laboratory Manual. The Benjamin / Cummins Publishing Company Inc., California.

El-Sersy, N.A., Abd-Elnaby, H., Abou-Elela, G.M., Ibrahim, H.A.H. and El-Toukhy, N.M.K. $2010 . \quad$ Optimization, economization and characterization of cellulase produced by marine Streptomyces ruber. African J. Biotechnol. 9(38): 6355-6364.

Ezekiel, C.N., Odebode A.C., Omenka R.O. and Adesioye F.A. 2010. Growth response and comparative cellulase induction in soil fungi grown on different cellulose media. acta SATECH. 3(2): 52-59.

Fourti, O., Jedidi, N. and Hassen, A. 2008. Behaviour of main microbiological parameters and of enteric microorganisms during the composting of municipal solid wastes and sewage sludge in semiindustrial composting plant. American J. 
Environ. Sci. 4(2): 103-110.

Gautam, S.P., Bundela, P.S., Pandey, A.K., Awasti, M.K. and Sarsaiya, S. 2010. Screening of cellulolytic fungi for management of municipal solid waste. J. Appl. Sci. Environ. Sanit. 5(4): 391-395.

Golinska, P. and Dahm, H. 2011. Enzymatic activity of actinomycetes from the genus Streptomyces isolated from the bulk soil and rhizosphere of the Pinus sylvestris. Dendrobiol. 65: 37-46.

Gupta, P., Samant, K. and Sahu, A. 2012. Isolation of cellulose-degrading bacteria and determination of their cellulolytic potential. Internat. J. Microbiol. 2012: 15.

Hankin, L. and Anagnostakis, S.L. 1977. Solid media containing carboxymethylcellulose to detect $\mathrm{C}_{\mathrm{x}}$ cellulase activity of microorganisms. J. Gen. Microbiol. 98: 109-115.

Hendricks, C.W., Doyle, J.D. and Hugley, B. 1995. A new solid medium for enumerating cellulose-utilizing bacteria in soil. App. Environ. Microbiol. 6(5): 20162019.

Jahangeer, S., Khan, N., Jahangeer, S., Sohail, M., Shahzad, S., Ahmad, A. and Khan, S.A. 2005. Screening and characterization of fungal cellulases isolated from the native environmental source. Pak. J. Bot. 37(3): 739-748.

Jaradat, Z., Dawagreh, A., Ababneh, Q. and Saadoun, I. 2008. Influence of culture conditions on cellulase production by Streptomyces sp. (strain J2). Jordan J. Biol. Sci. 1(4): 141-146.

Jeffrey, L.S.H. and Azrizal, M.R. 2007. Screening for cellulase activities in actinomycetes isolated from different locations of Peninsular Malaysia. J. Trop. Agric. Fd. Sci. 35(1): 153-157.

Krishna Kumari, K., Ponmurugan, P. and Kannan, N. 2006. Isolation and characterization of Streptomyces sp. from soil samples for secondary metabolite production. Biotechnol. 5(4): 478-480.

Lechevalier, H. A. 1989. The actinomycetes III. A practical Guide to Generic
Identification of Actinomycetes. In Bergey's Manual of Systemic Bacteriology. Williams and Wilkins Company, Baltimore. 4: 2344-2347.

Lu, W.J., Wang, H.T., Yang, S.J., Wang, Z.C. and Nie, Y.F. 2005. Isolation and characterization of mesophilic cellulosedegrading bacteria from flower stalksvegetable waste co-composting system. J. Gen. Appl. Microbiol. 51(6): 353-360.

Majidi, S., Roayaei, M. and Ghezelbash, G. 2011. Carboxymethyl-cellulase and filterpaperase activity of new strains isolated from Persian Gulf. Microbiol. J. 1(1): 816.

Mandels, M. and Weber, J. 1969. The production of cellulases. In: Cellulases and their applications. G.J. Hajny, E.T. Resse (ed.), Amer. Chem. Soc. Adv. Ser. 95: 391-414.

Miller, G.L., Blum, R., Glennon, W.E. and Burton, A.L. 1960. Measurement of carboxymethyl cellulase activity. Analytical Biochem. 2: 127-132

Mirdamadian, S.H., Khayam-Nekoui, S.M. and Ghanavati, H. 2011. Reduce of fermentation time in composting process by using a special microbial consortium. Engg. Technol. 52: 533-537.

Mythili, B. and Ayyappa Das, M.P. 2011. Studies on antimicrobial activity of Streptomyces spp. isolates from Tea plantation soil. Res. J. Agril. Sci. 2(1): 104-106.

Naveenkumar, K.J. and Thippeswamy, B. 2013. Isolation and screening of potential cellulolytic fungi from arecanut husk waste. Int. J. Curr. Sci. 8: 125-132.

Nonoh, J.O., Lwande, W., Masiga, D., Herrmann, R., Presnail, J.K., Schepers, E., Okech, M.A., Bagine, R., Mungai, P., Nyende, A.B. and Boga, H.I. 2010. Isolation and characterization of Streptomyces species with antifungal activity from selected national parks in Kenya. Afr. J. Microbiol. Res. 4(9): 856864.

Novinsak, A., Surette, C., Allain, C. and Filion, M. 2008. Application of molecular 
technologies to monitor the microbial content of biosolids and composted biosolids. Water Sci. Technol. 57: 471477.

Oskay, M., Tamer, A.U. and Azeri, C. 2004. Antibacterial activity of some actinomycetes isolated from farming soils of Turkey. African J. Biotechnol. 3(9): 441-446.

Otajevwo, F.D. and Aluyi, H.S.A. 2011. Cultural conditions necessary for optimal cellulase yield by cellulolytic bacterial organisms as they relate to residual sugars released in broth medium. Mod. Appl. Sci. 5(3): 141-151.

Rathnan, R.K., Nair, P. and Balasaravanan, T. 2012. Isolation, identification and characterization of efficient cellulolytic fungi from natural resources. Internat. J. Microbial Res. Technol. 1(4): 379-387.

Ray, P and Rath, S. 2007. Occurrence of cellulase in soil fungi. J. Microb. World. 9(1): 172-174.

Reddy, N.G., Ramakrishna, D.P.N. and Raja Gopal, S.V. 2011. A morphological, physiological and biochemical studies of marine Streptomyces rochei (MTCC 10109) showing antagonistic activity against selective human pathogenic microorganisms. Asian J. Biol. Sci. DOI: 10.3923/ajbs. 1-14.

Shahriarinour, M., Mohd Noor, A.W., Ariff, A. and Mohamad, R. 2011. Screening, isolation and selection of cellulolytic fungi from oil palm empty fruit bunch fibre. Biotech. 10(1): 108-113.

Shankar, T., Mariappan, V. and Isaiarasu, L. 2011. Screening cellulolytic bacteria from the mid-gut of the popular composting earthworm, Eudrilus eugeniae (Kinberg). World J. Zoo. 6(2): 142-148.

Shiva Reddy, D.M., Mohan, B.K., Nataraja, S., Krishnappa, M. and Abhilash, M. 2010. Isolation and molecular characterization of Bacillus megaterium isolated from different agro climatic zones of Karnataka and its effect on seed germination and plant growth of Sesamum indicum. Res. J. Pharma., Biol. Chem. Sci. 1(3): 614-625.

Singh, R. and Kapoor, V. 2013. Biochemical characterization of thermophilic actinomycetes (Streptomyces sp. MSC702) from mushroom compost in India. Int. J. Curr. Biotechnol., 1(10): 1-7.

Subramanian, C.V. 1971. Hypomycetes on account of Indian species, except Cercospora. ICAR Publication, New Delhi, India, pp. 1-929.

Teather, R.M. and Wood, P.J. 1982. Use of Congo red-polysaccharide interactions in enumeration and characterization of cellulolytic bacteria from bovine rumen. Applied Environ. Microbiol. 43: 777-780

Waksman, S.A. 1961. The Actinomycetes: Classification, Identification and Description of Genera and Species. Baltimore: The Williams and Wilkins Company. Vol. 2: 61-292.

\section{How to cite this article:}

Game, B.C., C.D. Deokar and Jadhav, A.C. 2018. Characterization of Cellulolytic Microorganisms Associated with Naturally Decomposing Waste Material. Int.J.Curr.Microbiol.App.Sci. 7(04): 1710-1719. doi: https://doi.org/10.20546/ijcmas.2018.704.194 